\title{
Factors influencing the fertility of a cattle population
}

\author{
A. De Kruif \\ Clinic of Veterinary Obstetrics, Gynaecology and A.I., State University of Utrecht, "De Uithof", \\ Utrecht, Netherlands
}

\begin{abstract}
Summary. The many factors which may influence the fertility of a cattle population are reviewed. The following subjects are discussed: the bull, the method of insemination, the cow, the conditions of herd management and chance. Particular attention is paid to factors related to the conditions of herd management. These are the climate, the season, the size of the herd, the housing system, the choice of a bull, hygiene at the time of calving, the interval between parturition and the first insemination, detection of oestrus, the time of insemination during oestrus, nutrition, selection and the culling of cows. In the discussion, the effect which the various factors may have on fertility is illustrated by a case in point.
\end{abstract}

On a large number of cattle farms, reproduction does not follow an optimum course. As reproduction plays an important role in the entire economy of a cattle farm (Louca \& Legates, 1968; Esslemont, 1974), it is essential that reproductive failure should be traced to its source as rapidly as possible. This requires detailed analysis and interpretation of the data on reproduction. This is only possible, however, when there is a clear understanding of the many factors which influence fertility in a cattle population. Only then can a definite opinion on fertility be reached and those measures be adopted that will result in the disappearance of any reproductive failure which may be present.

Before proceeding to discuss the various factors which may affect fertility, the concept of fertility should be specified. Fertility of a herd is best determined when three criteria are adopted: (a) the pregnancy rate after the first insemination; (b) the number of inseminations per conception; and (c) the average interval between parturition and conception. By adopting these criteria and applying a formula, it may be possible to express fertility as a figure (Fertility Status; De Kruif, 1975a). From now onwards, the above criteria will be used wherever possible. The many factors which may influence these criteria may broadly be classified as (1) the bull; (2) the method of insemination; (3) the cow; (4) the conditions of herd management; (5) chance. After discussion of these factors, an attempt will be made to elucidate the relative importance of each one.

The bull

When natural service is employed, then it regularly happens that the bull is the cause of the failure of cows to become pregnant (Ayalon, 1964; Roberts, 1971). However, it is beyond the scope of this paper to discuss the many causes of inadequate fertility of the bull. When A.I. is used, the fertility of the bulls employed is usually calculated and those bulls which fail to fertilize or do so inadequately are eliminated by selection. All the same, there continue to be considerable differences in fertility between the remaining bulls. A difference of $15 \%$ with regard to conception rate after the first insemination between the bull displaying the best and the bull showing the poorest fertilizing capacity is a common phenomenon in A.I. centres of average size. Particular bulls, for instance those of which the semen does not lend itself readily to freezing, occasionally show even poorer results (Mann, 1976). It will therefore be necessary to study the fertility of the A.I. bull(s) most commonly used in a herd.

\section{Method of insemination}

A satisfactory method of insemination is essential for obtaining high fertilization rates (Roberts, 1971 ; Paufier, 1974). In almost all A.I. centres, there are marked differences between the various inseminators as regards fertilization rates. These differences often range from 5 to $10 \%$. The rates 
Table 1. Relationship between age and calving rate after the first insemination and interval between parturition and conception (after De Kruif, 1975a)

\begin{tabular}{ccccc}
\hline $\begin{array}{c}\text { Age } \\
\text { (years) }\end{array}$ & $\begin{array}{c}\text { No. of } \\
\text { cows }\end{array}$ & $\begin{array}{c}\text { Calving rate } \\
\text { after first } \\
\text { insemination }\end{array}$ & $\begin{array}{c}\text { No. of } \\
\text { cows }\end{array}$ & $\begin{array}{c}\text { Time between } \\
\text { parturition and } \\
\text { conception (days) }\end{array}$ \\
\hline 2 & 15328 & $55 \cdot 9$ & 8880 & $109 \cdot 9$ \\
3 & 16019 & $60 \cdot 5$ & 10476 & $105 \cdot 7$ \\
4 & 13013 & $63 \cdot 0$ & 9000 & $103 \cdot 4$ \\
9 & 2321 & $53 \cdot 6$ & 1161 & $106 \cdot 0$ \\
$\geqslant 13$ & 325 & $42 \cdot 0$ & 107 & 110.9 \\
\hline
\end{tabular}

obtained by a single inseminator may actually show a marked decrease: experience shows that this is usually due to problems in private life. Adequate checks on the results obtained by each inseminator are extremely useful to be able to detect any sudden decline in conception rates as soon as possible.

\section{The cow}

Age

The age of the cow has a marked effect on the pregnancy rate after the first insemination (Boyd \& Reed, 1961a; Van Dieten, 1964, 1968; De Kruif, 1975b). It is concluded by nearly all investigators that the pregnancy rate is reduced in those animals which have calved for the first time. De Kruif $(1975 \mathrm{~b})$, for instance, observed a difference of $5 \%$ in pregnancy rate between primiparous and secundiparous cows (Table 1).

In animals over 7 years of age, pregnancy rates following the first insemination will also be lower. The relationship between age and length of the interval between parturition and conception was also studied (Andersen, 1966; Flores, 1972; De Kruif, 1975b). All these authors report that this interval is longer in those animals which have calved for the first time than it is in triparous and quadriparous cows (Table 1). The majority of investigators do not attribute the reduced conception rates in primiparous cows to their age but to the fact that it is precisely in these animals that more problems arise at the time of parturition and during the puerperium. This was verified by De Kruif (1975b), who compared primiparous cows which had calved normally and in which the placenta had not been retained with a similar group of secundiparous, triparous and quadriparous cows, and showed that the differences had disappeared.

\section{Infections}

Previously, venereal infection (Vibrio fetus and Trichomonas foetus) was an important factor in the problem of herd infertility in a great many countries (Roberts, 1971; Carrol \& Hoerlein, 1972; Winter, 1973). The incidence of these infections has been markedly reduced, particularly as a result of veterinary measures and the use of artificial insemination. In a number of countries, however, these infections continue to be important causes of diminished fertility of the cattle population. Another infection which may cause considerable losses is Brucella abortus (Roberts, 1971). The infection has also been almost completely eradicated in a number of countries (Bane, 1964; Roberts, 1971) and, in others, animals are being vaccinated (Zemjanis, 1974). In those countries, however, in which standards of cattle farming are lower, considerable efforts will be required to eliminate this infection. A large number of other infections may also give rise to abortion (IBR virus, leptospirosis, bovine viral diarrhoea), occasionally accompanied by retained placenta and subsequent metritis and infertility (Hanson, 1960; McKercher, 1969; Storz, 1971; Kahrs, 1973; Kirkbride et al., 1973; Williams, Shreeve, Herbert \& Swize, 1977). Infectious pustular-vulvo-vaginitis (IPV) infections may be an incidental cause of diminished fertility. When natural service is employed, only vaginitis will occur and fertility usually does not show a decrease (Bouters, Vandeplassche, Florent \& Leunen, 1964; Parsonson \& Snowdon, 1975). When, on the other hand, semen infected with IPV virus is introduced 
into the uterus, this frequently results in endometritis and a decrease in pregnancy rates. Adequate inspection of A.I. bulls is therefore essential (Bouters et al., 1964; Kendrick \& McEntee, 1967).

The extent to which other forms of infection (mycoplasmosis, chlamydiasis, bovine viral diarrhoea) affect fertility is more or less obscure. The literature on the subject is often contradictory (Schoop, Krüger-Hansen \& Wachendorfer, 1965; Hirth, Plastridge, Tourtellotte \& Nielson, 1966; Archbald, Gibson, Schultz, Fahning \& Zemjanis, 1973; Langford, 1975).

Infections of the genital tract which are due to inadequate hygiene at the time of parturition are discussed below.

\section{Individual pathological changes}

As a result of fortuitous causes, various individual pathological conditions may involve problems in a herd (for instance, urovagina, hydrosalpinx, adhesions, cystic ovarian disease). When a number of these conditions occur concurrently in a herd, as the result of coincidence, fertility may be impaired to a considerable extent. Detailed clinical studies will then reveal the presence of these abnormalities in a large number of individuals.

\section{Conditions of herd management}

\section{Climate}

The climate is an important factor for the conception of cattle (Thatcher, 1974; Gwazdauskas, Wilcox \& Thatcher, 1975). High temperatures and a high degree of humidity will result in less marked signs of oestrus and reduced conception rates (Stott, Wiersma \& Woods, 1972; Vincent, 1972; Gwazdauskas, Thatcher \& Wilcox, 1973; Monty \& Wolff, 1974; Wolff \& Monty, 1974). The proportion of cows in which embryonic death occurs is believed to be much higher in the tropics than it is in the more temperate zones (Stott \& Williams, 1962).

\section{Season}

The results of insemination vary from month to month. In temperate regions, pregnancy rates are highest in the spring (Mercier \& Salisbury, 1947; De Kruif, 1975b) and results are decidedly less satisfactory during the autumn and winter months (Table 2). The consensus is that the poorer results obtained during the winter season are attributable to a set of factors such as: fewer hours of daylight, less obvious signs of oestrus and less efficient detection of oestrus (Cohen, 1956; Andersen, 1966; Deas, 1971; Roine, 1973; Kordts, 1974; De Kruif, 1975b). The interval between parturition and conception is longest in those cows which have calved in autumn (Andersen, 1966; De Kruif, 1975b); e.g. in cows which calved in October, the interval was almost 1 month longer than in animals which calved in April. Hewett (1968) observed that cows which had calved in the autumn included a larger proportion of repeat breeders (failure to become pregnant after as many as 3 inseminations) than did those which had calved in spring. Hewett attributed this finding to the fact that detection of oestrus was poorer during the winter months.

Table 2. Relationships between the month during which the first insemination took place and the calving rate after the first insemination and between the month of parturition and the interval between parturition and conception (De Kruif, 1975a)

\begin{tabular}{lccccc}
\hline $\begin{array}{c}\text { Month of } \\
\text { first } \\
\text { insemination }\end{array}$ & $\begin{array}{c}\text { No. of } \\
\text { cows }\end{array}$ & $\begin{array}{c}\text { Calving rate } \\
\text { after first } \\
\text { insemination }\end{array}$ & $\begin{array}{c}\text { Month of } \\
\text { parturition }\end{array}$ & $\begin{array}{c}\text { No. of } \\
\text { cows }\end{array}$ & $\begin{array}{c}\text { Time between } \\
\text { parturition and } \\
\text { conception (days) }\end{array}$ \\
\hline January & 5507 & $54 \cdot 1$ & January & 5435 & $109 \cdot 3$ \\
April & 8099 & 56.9 & April & 4862 & $93 \cdot 0$ \\
June & 10812 & 66.5 & June & 2244 & $101 \cdot 5$ \\
July & 6525 & 63.8 & July & 1508 & $105 \cdot 8$ \\
October & 2215 & $59 \cdot 5$ & October & 2793 & $119 \cdot 1$ \\
\hline
\end{tabular}




\section{Size of the herd}

A large number of studies have been concerned with a possible effect of the size of the herd on the pregnancy rate after the first insemination. It is concluded by almost all investigators that the pregnancy rate decreased with the size of the herd (Andersen, 1966; Olds \& Deaton, 1968; Van Dieten, 1968; Ayalon, Harrari, Lewis, Pasener \& Cohen, 1971; MacMillan \& Watson, 1971; De Kruif, 1975b). Fewer studies have been concerned with the relationship between the size of the herd and the interval between parturition and conception. It is concluded by De Kruif (1975b) that this interval is shorter in large herds than in small herds (Table 3), because insemination is started sooner after parturition in the former. This shorter interval between parturition and first insemination might account in part for the lower pregnancy rates recorded in the larger herds. Hewett (1968) showed that repeat breeders are more common in the larger herds than in small herds. In the very small herds $8.5 \%$ of the animals failed to become pregnant after as many as three inseminations, whereas this proportion was $13.1 \%$ in the larger herds. It should be pointed out, however, that these studies were concerned with herds which usually included less than 30 cows.

\section{Housing system}

The manner in which the cows are housed was found to affect the pregnancy rate after the first insemination (Willems, 1971). The average rate is higher when systems are adopted in which the cows have freedom of movement (loose housings or loose housings with cubicles) than it is in tying stalls. The differences between the herds were found to have disappeared during the grazing season. Freedom of movement not only increases the intensity of the signs of oestrus (Kiddy, 1977) but also stimulates the onset of the cycle after parturition, particularly in primiparous animals (Kordts \& Gravert, 1972; De Kruif, 1977). Thus inactive ovaries are less common in animals in loose housings than they are in those in tying stalls. In tying stalls, in which the quantity of light which enters is inadequate, detection of oestrus is particularly difficult and the conception rates are often very poor. Alterations in the housing system, such as switching from tying stalls to loose housings with cubicles, which are often accompanied by enlargement of the herd as new cows have been purchased, will occasionally result in lower conception rates. The results obtained will not show any improvement until dairymen and cows have adjusted themselves to the new situation (Williams, 1960; De Kruif, 1975a).

\section{Management}

Management is made up of a large number of entities which are of vital importance to fertility.

Choice of the bull. Many problems of parturition are due to the fact that the calf is too heavy. These problems can largely be avoided when the dairyman has his heifers inseminated with semen of bulls known to produce smooth deliveries (Van Dieten, 1963; Philipsson, 1976; Remmen, 1976). Difficulties at parturition frequently result in changes of the genital tract (endometritis, adhesions), which are detrimental to subsequent fertility (Konermann, Daerr \& Frerking, 1969; Ayalon et al., 1971 ; Baier, Bostedt \& Schmidt, 1973; Laster, Glimp, Curdiff \& Gregory, 1973; De Kruif, 1975b).

Table 3. Relationships between the size of the herd and the calving rate after the first insemination, the interval between parturition and conception and the interval between parturition and first insemination (De Kruif, 1975a)

\begin{tabular}{|c|c|c|c|c|c|c|}
\hline $\begin{array}{c}\text { Size of } \\
\text { herd }\end{array}$ & $\begin{array}{l}\text { No. of } \\
\text { cows }\end{array}$ & $\begin{array}{l}\text { Calving rate } \\
\text { after first } \\
\text { insemination }\end{array}$ & $\begin{array}{l}\text { No. of } \\
\text { cows }\end{array}$ & $\begin{array}{c}\text { Time between } \\
\text { parturition and } \\
\text { conception (days) }\end{array}$ & $\begin{array}{l}\text { No. of } \\
\text { cows }\end{array}$ & $\begin{array}{c}\text { Time between } \\
\text { parturition and } \\
\text { first insemination } \\
\text { (days) }\end{array}$ \\
\hline $1-10$ & 2790 & $61 \cdot 1$ & 1786 & $113 \cdot 5$ & 1808 & $97 \cdot 8$ \\
\hline $11-20$ & 20549 & $61 \cdot 2$ & 13300 & $108 \cdot 4$ & 13560 & $92 \cdot 6$ \\
\hline $21-30$ & 23737 & $59 \cdot 6$ & 14920 & $106 \cdot 1$ & 15292 & $89 \cdot 6$ \\
\hline $31-40$ & 14796 & $58 \cdot 1$ & 8782 & $103 \cdot 2$ & 9005 & $87 \cdot 3$ \\
\hline $41-50$ & 6993 & $57 \cdot 2$ & 3982 & $102 \cdot 1$ & 4070 & 86.4 \\
\hline $51-60$ & 3400 & $57 \cdot 3$ & 18895 & $101 \cdot 8$ & 1954 & 86.8 \\
\hline$\geqslant 61$ & 3045 & $55 \cdot 6$ & 1560 & $99 \cdot 0$ & 1622 & 85.0 \\
\hline Total & 75310 & $59 \cdot 3$ & 46225 & $105 \cdot 7$ & 47311 & 89.9 \\
\hline
\end{tabular}


Inbreeding should be avoided as this may result in lower pregnancy rates. On the other hand, the hybrid vigour associated with outbreeding may give rise to higher pregnancy rates (Mares, Menge, Tyler \& Casida, 1961; Conneally, Stone, Tyler, Casida \& Morton, 1963; Pirchner, Chakzabarti, Erlacher, Schleger \& Rohrbacher, 1971). Pregnancy rates vary with semen quality. When the dairyman does not intend to retain the calves, the selected bulls should be those known to produce high fertility rates (Olds, 1969).

Hygiene at the time of calving. It has long been known that inadequate hygiene at the time of calving may give rise to a wide variety of changes of the genital tract (De Bois, 1961; Roberts, 1971), particularly retained placenta and endometritis. These conditions will result in $5-10 \%$ lower pregnancy rates after the first insemination and a longer interval between parturition and conception (Brands, 1966; Morrow, Roberts \& McEntee, 1969a, b; Bach \& Priebus, 1972; De Kruif, 1975a; Pelissier, 1976). Hygiene is of particular importance in loose housings or loose housings with cubicles, in which large numbers of cattle are kept. There is close contact between the cows, resulting in a markedly increased risk of infection. Problems are particularly common on those farms on which the cows are housed in summer as well as in winter (De Kruif, 1975a). On these farms, cows should calve in optimum conditions (calving pen, thorough cleansing of the hindquarters of the cow, etc.).

Interval between parturition and the first insemination. The interval between parturition and the first insemination has been often discussed (VanDemark \& Salisbury, 1950; Shannon, Salisbury \& VanDemark, 1952; Trimberger, 1954; Erb \& Holtz, 1958; Touchberry, Rottensten \& Andersen, 1959; Boyd \& Reed, 1961b; Friedrich, 1964; Olds \& Cooper, 1970; Flores, 1972; Kräusslich, 1974; Britt, 1975; De Kruif, 1975a). The interval between parturition and conception is composed of the interval between parturition and the first insemination and that between the first insemination and conception. All these studies showed that the pregnancy rate after the first insemination increased, that the number of inseminations per conception decreased and that the interval between parturition and conception lengthened as the interval between parturition and the first insemination increased. The highest pregnancy rate after the first insemination was achieved when the interval between parturition and the first insemination was around 100 days. When this interval was shorter than 40 days pregnancy rates showed a rather sharp decline. In that case, however, the interval between parturition and conception was also short (Table 4). Assessment of fertility should not be based, therefore, on a single criterion such as the pregnancy rate but on all criteria in conjunction with each other. Low pregnancy rates are by no means invariably evidence of poor fertility! Accordingly, insemination soon after parturition will result in a lower pregnancy rate but there will be a shorter interval between parturition and conception. This is profitable financially because a short interval between parturition and conception will increase the milk and calf yields per annum (Louca \& Legates, 1968; Esslemont, 1974). When insemination is carried out soon after parturition (within 60 days), it is essential that this should only be done in cows which have calved normally and had a normal puerperium (Machnai \& Kali, 1971; De Kruif, 1975a). When early insemination is carried out in cows in which parturition or the puerperium ran an abnormal course, pregnancy rates will show an extremely marked decrease. Studies on possible adverse effects on reproduction (e.g. an increase in irregular cycles, more repeat breeders or an increased incidence of abortion) when insemination is carried out soon after parturition have revealed no detectable effects (Shannon, Salisbury \& VanDemark, 1952; Olds \& Cooper, 1970; Whitmore, Tyler \& Casida, 1974a; De Kruif, 1975a).

Detection of oestrus. One of the most important elements of management of a cattle herd is detection of oestrus. Its neglect may give rise to a wide variety of problems related to the fertility of the herd. Naturally, too few animals in oestrus are detected in time, and this results in an unduly long interval between parturition and the first insemination (Table 4) and thereby in too long an interval between parturition and conception (Bozworth, Ward, Call \& Bonewitz, 1972; Esslemont \& Ellis, 1974; Barr, 1975; Pelissier, 1976). Cows which have previously been inseminated and failed to conceive will often pass unnoticed because of inadequate detection of oestrus. This will result in an unduly long interval between inseminations and consequently also in an unduly long interval between parturition and conception (Olds, 1969; Esslemont, 1974). Moreover, as a result of inadequate detection of oestrus, cows which are not in oestrus (cyclic or pregnant) are frequently 
Table 4. Effect of mean interval between calving and first service, conception rate and oestrus detection rate on mean interval between calving and conception (in days) (Esslemont \& Ellis, 1974)

\begin{tabular}{|c|c|c|c|c|c|c|}
\hline \multirow{3}{*}{$\begin{array}{l}\text { Mean interval } \\
\text { from calving } \\
\text { to first } \\
\text { service (days) }\end{array}$} & \multicolumn{6}{|c|}{ Average conception rate $(\%)$} \\
\hline & \multicolumn{3}{|c|}{$50 \%$ detection rate } & \multicolumn{3}{|c|}{$80 \%$ detection rate } \\
\hline & 40 & 50 & 60 & 40 & 50 & 60 \\
\hline 50 & 110 & 92 & 78 & 87 & 76 & 67 \\
\hline 60 & 120 & 102 & 88 & 97 & 86 & 77 \\
\hline 70 & 130 & 112 & 98 & 107 & 96 & 87 \\
\hline 80 & 140 & 122 & 108 & 117 & 106 & 97 \\
\hline 90 & 150 & 132 & 118 & 127 & 116 & 107 \\
\hline
\end{tabular}

submitted for insemination. These cows will naturally return to oestrus (often irregularly) and give rise to a low pregnancy rate after insemination and too large a number of inseminations is required for each conception. (Endometritis may occur incidentally in these cows because the resistance of the uterus to bacteria is lowered during the luteal phase (Roberts, 1971; Gunnink, 1973).)

The above findings clearly show that inadequate detection of oestrus may give rise to very serious problems in a herd. In the literature, considerable attention is therefore paid to this component of herd management and much advice is offered (Hartigan, 1972; Esslemont, 1974; Foote, 1975; Sorensen, 1975; O'Farrell, 1975; Appleyard \& Cook, 1976; Boyd, 1977). The fact is invariably stressed that successful detection of oestrus will only be possible when cows can be recognized (identification system) and adequate records are kept. These are precisely those components of management which cause problems to many dairymen (Conlin, 1974; Esslemont, 1974; Foote, 1975) and the degree of detection of oestrus depends on the technical skill of the dairyman (Williamson, Morris, Blood \& Cannon, 1972; Pelissier, 1976). It is apparent from several studies that almost all cows in a herd show signs of oestrus but that these are inadequately observed, particularly in large herds (Zemjanis, Fahning \& Schulz, 1969; Williamson et al., 1972; Esslemont, 1974; Hurnik, King \& Robertson, 1975; De Kruif, 1975a). In these large herds, considerable technical skill is required for dairymen to detect oestrus, and some are better able to do so than others, even though records are in order and sufficient time is spent on observation. Silent heat is therefore a matter of management rather than of cows.

Time of insemination during oestrus. Particularly in artificial insemination, it is essential that the cow should be inseminated between the middle and the end of the period of oestrus (Trimberger \& Davis, 1943; Bane, 1964; Roberts, 1971). When insemination is carried out during the early part of oestrus, fewer cows will conceive, particularly when the semen is of indifferent or inferior quality. Inseminations carried out after ovulation has occurred will also result in lower pregnancy rates (Trimberger \& Davis, 1943; Boyd, 1970; Deas, 1970).

Nutrition and milk yield. In the literature, the nutrition is frequently referred to as the cause of inadequate fertility. In the course of time, deficiencies in and excesses of an unusually large number of feeds, minerals, trace elements and vitamins have been stressed. Therefore, it is particularly difficult to enter deeply into this matter within the scope of the present paper and a number of reviews on the subject are available (Lamond, 1970; King, 1971; Broster, 1973; Lotthammer \& Ahlswede, 1973; Lotthammer, 1974; Parker \& Blowey, 1976; Francos, Davidson \& Mayer, 1977). Study of the literature shows that opinions on the effect of the various nutrients differ markedly. Local differences and conditions play an important role in this regard. However, a general comment would appear to be in place. Roughly speaking the first symptom to appear when the diet is wrong is a decrease in milk production. Fertility will only be affected at a later stage. In the Netherlands, for example, the diet is not believed to be of much importance as a cause of breeding insufficiency. Dietary errors may naturally be associated with reproductive disorders but impaired reproduction is often not due to an error in the diet but both problems may have been created by a dairyman of low skill. Infertility due to nutritional causes is usually characterized by a failure of oestrus and only under 
certain conditions is it characterized by a failure of conception or early embryonic death (Roberts, 1971). Sometimes infertility may be associated with the consumption of phyto-oestrogens from plants (clover, alfalfa, sugarbeet) (Adler \& Trainin, 1960; Kallela, 1964; Lotthammer \& Ahlswede, 1973).

The milk yield is closely related to the diet. Opinions on the effect of the milk yield on fertility are also divided. Some workers were able to show that the milk yield had a marked effect (Hewett, 1968; Francos \& Rattern, 1975; Spalding, Everett \& Foote, 1975), others failed to do so (Metz \& Politiek, 1970; Koopman \& Wijbenga, 1973, 1975). A diagnosis of cystic ovarian disease is more common in cows with high milk yield than it is in those showing lower milk yields (Roberts, 1971b; Whitmore et al., 1974b). It is doubtful, however, whether there is a genetic correlation between the milk yield and cystic ovarian disease (Casida \& Chapman, 1951; Menge, Mares, Tyler \& Casida, 1962).

Selection. Faulty selection of cows may give rise to a number of problems. Among these are hypoplasia of the gonads, e.g. in Swedish Highland cattle (Lagerlöf \& Settergren, 1953; Lagerlöf \& Boyd, 1953), white heifer disease (Bennett, Olds, Deaton \& Thrift, 1973) and cystic ovarian disease (Garm, 1949; Sonnenbrodt \& Ranninger, 1950; Henricson, 1956; Foote, 1970; Wegner, 1973). Cystic ovarian disease may be common in particular families, especially when bulls descended from these families are used. Selecting animals for specific fertility characters such as non-return or conception rates or the intensity of oestrus is impractical in field conditions because heritability is too low (Rottensten \& Touchberry, 1957; Inskeep, Tyler \& Casida, 1961 ; Hahn, 1969; Foote, 1970; Wegner, 1973; Kräusslich, Osterkorn \& Richter, 1977). Most fertility disorders are indeed the result of interaction between environment and genotype and therefore it is difficult to classify them as being strictly inherited or strictly acquired. Studies of lymphocyte chromosomes showed that the conception rates of female offspring sired by bulls bearing particular chromosome aberrations were reduced (Gustavsson, 1969; Fechheimer, 1973; Halnan, 1975). It should be borne in mind that there is a constant natural selection against factors which have an adverse effect on fertility. Natural selection will increase as the reduction of fertility caused by these factors increases (Gross Genital Abnormalities, 1966).

Culling cows. In correctly interpreting the findings on reproduction in a herd, it is essential to know the rate at which the dairyman culls those cows which fail to become pregnant. In other words, what is the average number of inseminations in each non-pregnant cow? In certain breeding and pedigree herds, insemination of particular valuable cows is occasionally continued over prolonged periods (Van Dieten, 1968). This may result in a long average interval between parturition and conception. On the other hand, in other herds cows that do not become pregnant immediately are culled rapidly, and this naturally has a beneficial effect on the interval between parturition and conception, as well as on the average number of inseminations per conception (Van Dieten, 1968).

\section{Chance}

Chance may be a factor, particularly in small herds (up to approximately 40 cows). Embryonic mortality is among the most important causes of failure of an animal to become pregnant. Bishop (1964) claims that each fertilization may be regarded as a genetic experiment which fails in $10-20 \%$ of the animals inseminated. These animals will therefore return to oestrus again (David, Bishop \& Cembrowicz, 1971). If the above should occur in several cows as a result of accidental conditions in a herd, fertility in a herd may be impaired during that year. In small herds, conception rates may therefore vary markedly from one year to another (Olds, Colvin, Cooper, Deaton, 1966; Olds, 1969; Stämpfli, 1973). Correct interpretation of the data on reproduction will only be possible in that case when this interpretation is based on the situation over a number of years.

\section{Discussion}

In the past, fertility was most severely impaired in many countries by infections of the genital tract. As these infections have been eradicated entirely or in part in various countries as a result of the development of an adequate veterinary infrastructure, other causes such as failings of management have become more outstanding. In countries in which infections (venereal) continue to be present, 
these should first be eliminated before much attention can be paid to the other causes of inadequate fertility. As is apparent from the above, the fertility of a cattle population may be affected by an exceptionally large number of factors in addition to infection. In turn, these factors often interact so that a correct interpretation of each individual factor is usually impossible. It is therefore difficult to assess correctly the fertility of a cattle population. As a rule, a number of criteria and the corresponding normal values are adopted in assessing fertility (Morrow, 1970; Roberts, 1971; De Kruif, 1975b). However, these normal values are based on local conditions and the effect of a large number of factors has already been discounted in these values. Therefore, it will be better to adopt 'ideal' values in which the various factors have not yet been taken into account. These 'ideal' values could be as follows for a cattle population:

- a pregnancy rate of $80 \%$ after the first insemination,

- a number of 1.3 inseminations per conception,

- an average interval of 85 days between parturition and conception.

In actual practice, it will be next to impossible to attain these ideal values as one or several factors will invariably exert an adverse effect. This is illustrated in studies by Boyd \& Reed (1961b) and by De Kruif (1975b). The latter compared pregnancy rates after the first insemination in two groups of cows. One group consisted of 3- to 6-year-old cows which had calved normally and had been inseminated during the period from 90 to 100 days after parturition in the months of May and June. The other group consisted of primiparae inseminated during the winter months, approximately 60 days after parturition. The pregnancy rate was $67 \%$ in the former and $48 \%$ in the latter group. The factor contributing most to this difference of $19 \%$ was the month of insemination, and the difference would have been even greater if semen of bulls showing good fertility had been used in one group and that of bulls showing inadequate fertility had been used in the other. If, moreover, insemination had been carried out by a highly skilled technician in one group and by a not-so-capable technician in the other, the total difference would have increased to $30-40 \%$. And should oestrus detection have involved problems in the second group (Table 4; Esslemont \& Ellis, 1974), then there obviously would have been a particularly marked difference between the two groups.

This is an extreme instance, but it clearly illustrates the great importance of the various factors. It is therefore understandable that reproduction does not reach an optimum level on a large number of cattle farms. What emerges from the literature is that the best thing to help those herds in which fertility is unsatisfactory, and/or which, as is usually the case, is due to failings in management, will be a herd fertility control programme (Morrow, 1966; Roberts, 1971 ; Stämpfli, 1973; Oxender, 1973; De Kruif, 1976). As visits are made to the farm at regular intervals, dairymen will be stimulated to pay special attention to the various factors influencing fertility in their herds. Improvement in management should primarily result in a shorter interval between parturition and conception.

\section{References}

Adler, J.H. \& Trainin, D. (1960) A hyperoestrogenic syndrome in cattle. Refuah Vet. 17, 115-122.

ANDERSEN, H. (1966) The effect of season of the year, age of the cow and size of the herd on fertility in cows. Arsberetn. Inst. Sterilitetsforskn. 227.

APPleYaRd, W.T. \& COOK, B. (1976) The detection of oestrus in dairy cattle. Vet. Rec. 99, 253-256.

Archbald, L.F., Gibson, C.D., Schultz, R.H., FahnING, M.L. \& Zemuanis, R. (1973) Effects of intra uterine inoculation of bovine viral diarrheamucosal disease virus on uterine tubes and uterus of nonpregnent cows. Am. J. Vet. Res. 34, 11331137.

Ayalon, N. (1964) Sterilitas sine materia. Proc. Sth Int. Congr. Anim. Reprod. \& A.I., Trento, V, 47-80.
Ayalon, N., Harrari, H.H., Lewis, J., Pasener, L.N. \& COHEN, Y. (1971) Relation of the calving-toservice interval to fertility in dairy cows with different reproductive histories, production levels and management practices. Refuah Vet. 28, 155-165.

BACH, S. \& Priebus, G. (1972) Untersuchungen zum Puerperalverlauf in Rinderherden. Mh. Vet. Med. 27, 499-502.

BAIER, W., Bosted , H. \& Schmidt, G. (1973) Uber die Fruchtbarkeitslage nach Schwergeburten beim Rind. Berl. Münch. Tierärztl. Wschr. 86, 3-7.

BANE, A. (1964) Fertility and reproductive disorders in Swedish cattle. Br. Vet. J. 120, 431-441.

BARR, H.L. (1975) Influence of estrus detection on days open in dairy herds. J. Dairy Sci. 58, 246-247.

Downloaded from Bioscientifica.com at $04 / 26 / 2023$ 10:32:35AM 
BennetT, R.C., Olds, D., Deaton, O.W. \& Thrift, F.A. (1973) Nature of white heifer disease (Partial Genital Aplasia) and its mode of inheritance. Am.J. Vet. Res. 34, 13-19.

Bishop, M.W.H. (1964) Paternal contribution to embryonic death. J. Reprod. Fert. 7, 383-396.

Bouters, R., Vandeplassche, M., Florent, A. \& LEUNEN, J. (1964) Virus infecties en steriliteit bij runderen. Vlaams Diergeneneesk. Tijdschr. 33, 405421.

BoYd, H. (1977) Anoestrus in cattle. Vet. Rec. 100, 150153.

BOYD, H. \& REED, H.C.B. (1961a) Investigations into the incidence and causes of infertility in dairy cattle-fertility variations. Br. Vet.J. 117, 18-31.

BOYD, H. \& REED, H.C.B. (1961b) Investigations into the incidence and causes of infertility in dairy cattle; influence of some management factors affecting the semen and insemination conditions. Br. Vet. J. 117, 74-86.

BoYD, H. \& ReED, H.C.B. (1961c) Investigations into the incidence and causes of infertility in dairy cows; influence of kale feeding, milk production and management. Br. Vet. J. 117, 192-200.

BoyD, L.J. (1970) Managing dairy cattle for fertility. $J$. Dairy Sci. 53, 969-972.

Bozworth, R.W., Ward, G., Call, E.P. \& Bonewitz, E.R. (1972) Analysis of factors affecting calving intervals of dairy cows. J. Dairy Sci. 55, 334-338.

BRANDS, A.F.A. (1966) Enige zoötechnische aspecten van retentio secundinarum bij runderen. Thesis, Utrecht.

BRITT, J.H. (1975) Early postpartum breeding in dairy cows. A review. J. Dairy Sci. 58, 266-281.

Broster, W.H. (1973) Live weight change and fertility in the lactating dairy cow: A review. Vet. Rec. 93, $417-420$.

Carroll, E.J. \& Hoerlein, A.B. (1972) Diagnosis and control of bovine genital Vibriosis. J. Am. vet. Ass. 161, 1359-1364.

Casida, L.E. \& Chapman, A.B. (1951) Factors affecting the incidence of cystic ovaries in a herd of Holstein cows. J. Dairy Sci. 34, 1200-1205.

CoHen, PH. (1956) Een statistisch onderzoek omtrent retentio secundinarum en enige andere, met de voortplanting samenhangende processen bij het rund. Thesis, Utrecht.

Conlin, B.J. (1974) Use of records in managing for good lactational and reproductive performance. $J$. Dairy Sci. 57, 377-385.

Conneally, P.M., Stone, W.H., Tyler, W.J., Casida, L.E. \& MoRTon, N.E. (1963) Genetic load expressed as fetal death in cattle. J. Dairy Sci. 46, 232-236.

DAvid, J.S.E., Bishop, M.W.H. \& Cembrowicz, H.J. (1971) Reproductive expectancy and infertility in cattle. Vet. Rec. 89, 181-185.

DeAs, D.W. (1970) The timing of insemination. Vet. Rec. $87,450-451$.

Deas, D.W. (1971) The effect of supplementary light on winter infertility in cattle. Vet. Rec. 89, 242.

DE Bois, C.H.W. (1961) Endometritis en vruchtbaarheid bij het rund. Thesis, Utrecht.

DE KRUIF, A. (1975a) Fertiliteit en subfertiliteit bij het vrouwelijk rund. Thesis, Utrecht.

DE KRUIF, A. (1975b) An investigation of the parameters which determine the fertility of a cattle population and of some factors which influence these parameters. Tijdschr. Diergeneesk. 100, 1089-1098.

DE KRUIF, A. (1976) A fertility control program in The Netherlands. Tijdschr. Diergeneesk. 101, 428-430.

DE KRUIF, A. (1977) Een onderzoek van runderen in anoestrus. Tijdschr. Diergeneesk. 102, 247-253.

ERB, R.E. \& HolTz, E.W. (1958) Factors associated with estimated fertilization and service efficiency of cows. J. Dairy Sci. 41, 1541-1552.

Esslemont, R.J. (1974) Economic and husbandry aspects of the manifestation and detection of oestrus in cows : I, II, III. $A D A S Q$. Ref. 12, 175-184; 13, 19$26 ; 15,83-95$.

Esslemont, R.J. \& Ellis, P.R. (1974) Components of a herd calving interval. Vet. Rec. 95, 319-320.

FeCHHEIMER, N.S. (1973) A cytogenetic survey of young bulls in the U.S.A. Vet. Rec. 93, 535-536.

Flores, A.G. (1972) A study of calving interval. Diss Abstr. B. 32, 4320.

Francos, G. \& Rattern, D. (1975) On the relation between milk production and fertility in Kibbutz dairy cattle herds. J. agric. Sci., Camb. 85, 527-531.

Francos, G., Davidson, N. \& Mayer, E. (1977) Influence of some nutritional factors on incidence of repeat breeder syndrome in high producing dairy herds. Theriogenology 7, 105-111.

FrIEDRICH, G. (1964) Einfluss der biologischen Rastzeit p.p. auf die Fruchtbarkeit des Rindes unter Berücksichtigung von Geburtstermin, Alter, Milchleistung und Abstammung. Thesis, Hannover.

FoOTE, R.H. (1970) Inheritance of fertility-facts, opinions and speculations. J. Dairy Sci. 53, 936-942.

Foote, R.H. (1975) Estrus detection and estrus detection aids. J. Dairy Sci. 58, 248-256.

Garm, O. (1949) A study on bovine nymfomania. Acta endocr., Copenh., Suppl. 3.

Gross Genital Abnormalities: the nature of subfertility in the dairy heifer (1966).

GưNICK, J.W. (1973) Een onderzoek naar het afweermechanisme van de uterus. Thesis, Utrecht.

Gustavsson, I. (1969) Cytogenetics, distribution and phaenotypic effects of a translocation in Swedish cattle. Hereditas 63, 68-73.

GWazdauskas, F.C., Thatcher, W.W. \& Wilcox, C.J. (1973) Physiological, environmental, and hormonal factors at insemination which may affect conception. J. Dairy Sci. 56, 873-877.

Gwazdauskas, F.C., Wilcox, C.J. \& Thatcher, W.W. (1975) Environmental and managemental factors affecting conception rate in a subtropical climate. $J$. Dairy Sci. 58, 88-92.

HAHN, J. (1969) Inheritance of fertility in cattle inseminated artificially. J. Dairy $S c i, 52,240-244$.

HaLnan, C.R.E. (1975) Chromosomes of cattle: present clinical status and promise. Vet. Rec. 96, 148-151.

Hanson, L.E. (1960) Bovine leptospirosis: A review. $J$. Dairy Sci. 43, 453-462.

Hartigan, P.J. (1972) The veterinarian and fertility in the dairy herd. Irish Vet. J. 26, 153-159.

Henricson, B. (1956) Genetical and statistical investigations into cystic ovaries in cattle. Proc. 3rd Int. Congr. Anim. Reprod. \& A.I., Cambridge, Vol. II, 49.

HEwETT, C.D (1968) A survey of the incidence of the 23 10:32:35AM 
repeat breeder cow in Sweden with reference to herd size, season, age and milk yield. Br. Vet.J. 124, 342352.

Hirth, R.F., Plastridge, W.N., Tourtellotte, M.E. \& Nielson, S.W. (1966) Genital Mycoplasmosis in cattle and man. J. Am. vet. med. Ass. 148, 277.

Hurnick, J.F., King, G.J., Robertson, H.A. (1975) Estrous and related behaviour in post-partum Holstein cows. Appl. anim. Ethol. 2, 55-68.

INSKeEP, E.K., Tyler, W.J. \& CASIdA, L.E. (1961) Hereditary variation in conception rates of HolsteinFriesian cattle. J. Dairy Sci. 44, 1857-1862.

KAHRS, R.F. (1973) Effects of Bovine Viral Diarrhea on developing fetus. $J$. Am. vet. med. Ass. 163, 877-878.

KALLELA, K. (1964) The incidence of plant oestrogens in Finnish pasture and fodder plants with special reference to their possible effects in cases of sterility in ruminants. Thesis, Helsinki.

KendRicK, W.J. \& MCENTEE, K. (1967) The effect of artificial insemination with semen contaminated with IBR-IPV virus. Cornell Vet. 57, 3-11.

KIDDY, C.A. (1977) Variation in physical activity as an indication of estrus in dairy cows. J. Dairy Sci. 60, 235-243.

KING, J.O.C. (1971) Nutrition and fertility in dairy cows Vet. Rec. 89, 320-324.

Kirkrride, C.A., Bicknell, E.J., Reed, D.E., Robl, M.G., KNUdTSON, W.U. \& Wohlgemuth, K. (1973) A diagnostic survey of bovine abortion and stillbirth in the northern plains states. $J$. Am. vet. med. Ass. 162, 556-560.

KonermanN, H., Daerr, H.C. \& Frerking, H. (1969) Fruchtbarkeit und Milchleistung nach Schwergeburten beim Rind. Dtsch. Tierärztl. Wschr. 79, 229234.

KOOPMAN, J.J. \& WIJBENGA, A. (1973) Vruchtbaarheid en melkproductie bij FH koeien in Noord-Holland. Tijdschr. Diergeneesk. 98, 565-576.

Koopman, J.J. \& WiJbenga, A. (1975) Nader onderzoek naar de invloed van bedrijfsomstandigheden en de melkproductie op de vruchtbaarheid. Tijdschr. Diergeneesk. 100, 875-882.

KORDTs, E. (1974) Möglichkeiten zur Verbesserung der Fruchtbarkeit weiblicher Rinder. Prakt. Tierarzt. 374-377.

KordTs, E. \& GraverT, K.O. (1972) Einflusz von künstlichem Licht und Bewegung auf die Fruchtbarkeit der Kühe. Proc. 7th Int. Congr. Anim. Reprod. \& A.I., München, III, 2016.

KRÄUSSLICH, H. (1974) Der Einfluss der Rastzeit auf verschiedene Fruchtbarkeitsparameter. Berl. Münch. Tierärztl. Wschr. 87, 276-278.

KräUSSLICH, K., OSTERKORN, K. \& RICHTER, H. (1977) Die züchterische Auswertung von Non-ReturnWerten in Besamungspopulationen. Züchtungskunde 49, 92-98.

LAGERLÖF, N. \& BOYD, H. (1953) Ovarian hypoplasia and other abnormal conditions in the sexual organs of cattle of the Swedich Highland Breed: results of post mortem examination of over 6000 cows. Cornell Vet. 43, 64-79.

LAgerlöF, N. \& Settergren, I. (1953) Results of 17 years' control of hereditary ovarian hypoplasia in cattle of the Swedish Highland Breed. Cornell Vet. $43,52-64$.
LAMOND, D.R. (1970) The influence of undernutrition on reproduction in the cow. Anim. Breed. Abstr. 38, 359-371.

LANGFORD, E.V. (1975) Mycoplasma species recovered from the reproductive tracts of Western Canadian Cows. Can. J. comp. Med. 39, 133-138.

LASTER, D.B., Glimp, H.A., CURdiff, L.V. \& Gregory, K.E. (1973) Factors affecting dystocia and the effects of dystocia on subsequent reproduction in beef cattle. J. Anim. Sci. 36, 695-705.

LotThammer, K.H. (1974) Häufige Fütterungsfehler als Ursache der Herdensterilität. Prakt. Tierarzt 55, 38-53.

LotThammer, K.H. \& AhLswede, L. (1973) Beziehungen zwischen Fütterung und Fruchtbarkeit beim weiblichen Rind: I + II. Ubersichten zur Tierernährung 1, 147-161, 325-353.

LoucA, A. \& Legates, J.E. (1968) Production losses in dairy cattle due to days open. J. Dairy Sci. 51, 573583.

MachNaI, B. \& KalI, J. (1971) Early insemination after parturition in three dairy herds. Refuah Vet. 28, 112115.

MacMillan, K.L. \& Watson, J.D. (1971) Short estrous cycles in New Zealand dairy cattle. J. Dairy Sci. 54, 1526-1529.

Mares, S.E., Menge, A.C., Tyler, W.J. \& CAsida, L.E. (1961) Genetic factors affecting conception rate and early pregnancy loss in Holstein cattle. $J$. Dairy Sci. 44, 96-103.

MANN, T. (1976) Relevance of physiological and biochemical research to problems in animal fertility. Proc. R. Soc. Lond. B 193, I-15.

MCKerChER, D.G. (1969) Cause and prevention of epizootic bovine abortion. J. Am. vet. med. Ass. 154, 1192-1196.

Menge. A.C., Mares, S.E., Tyler, W.J. \& Casida, L.E. (1962) Variation and association among post partum reproduction and production characteristics in Holstein-Friesian cattle. J. Dairy Sci. 45, 233-241.

Mercier, E. \& Salisbury, G.W. (1947) Fertility level in artificial breeding associated with season, hours of daylight and the age of cattle. J. Dairy Sci. 30, 817826.

Metz, J.H.M. \& Politiek, R.D. (1970) Fertility and milk production in Dutch Friesian cattle. Neth. $J$. agric. Sci. 18, 72-77.

Monty, D.E. \& WolfF, L.K. (1974) Summer heat stress and reduced fertility in Holstein-Friesian cows in Arizona. Am.J. vet. Res. 35, 1495-1500.

Morrow, D.A. (1966) Analysis of herd performance and economic results of preventive dairy herd health programs. Part I \& Part II. Vet. Med. 61, 474 \& 577.

MORROw, D.A. (1970) Diagnosis and prevention of infertility in cattle. J. Dairy Sci. 53, 961-969.

Morrow, D.A., Roberts, S.J. \& McEnTEe, K. (1969a) $A$ review of post partum activity and involution of the uterus and cervix in cattle. Cornell Vet. 59, 134 154.

Morrow, D.A., Roberts, S.J. \& McEnTeE, K. (1969b) Post partum ovarian activity and involution of the uterus and cervix in dairy cattle. I, II and III. Cornell Vet $59,173-190 ; 190-198 ; 199-210$, 
O'Farreli, K.J. (1975) The role of management in dairy herd fertility. Irish Vet.J. 29, 118-124.

OLDS, D. (1969) An objective consideration of dairy herd fertility. J. Am. vet. med. Ass. 154, 253-258.

OLDS, D. \& COOPER, T. (1970) Effect of post partum rest period in dairy cattle on the occurrence of breeding abnormalities and on calving intervals. $J$. Am. vet. med. Ass. 157, 92-97.

Olds, D. \& Deaton, O.W. (1968) Effect of herd size on fertility and delayed returns. Prog. Rep. Ky agric. Exp. Stn No. 32.

Olds, D., Colvin, L.D., Cooper, T. \& Deaton, O.W. (1966) Sources of variance affecting dairy herd fertility and delayed returns to service. J. Dairy Sci. 49, 1004-1005.

OXender, W.D. (1973) Dairy herd management and veterinary service in Michigan. Bovine Practitioner 8, 46-47.

PARKer, B.N.J. \& Blowey, R.W. (1976) Investigations into the relationship of selected blood components to nutrition and fertility of the dairy cow under commercial farm conditions. Vet. Rec. 99, 394-404.

ParsonsnN, J.M. \& SNOWDEN, W.A. (1975) The effect of natural and artificial breeding using bulls injected with, or semen contaminated with Infectious Bovine Rhinotracheites virus. Aust. vet. J. 51, 365-369.

PAUFLER, S.K. (1974) Künstliche Besamung und Eitransplantation bei Tier und Mensch. Verlag M. und $\mathrm{H}$. Schaper, Hannover.

Pelissier, C.L. (1976) Dairy cattle breeding problems and their consequences. Theriogenology 6, 575-583.

Philipsson, J. (1976) Studies on calving difficulty, stillbirth and associated factors in Swedish cattle breeds. Acta agric. scand. 26, 212-220.

Pirchner, F., Chakzabarti, S., Erlacher, J., SchleGER, W. \& ROHRBACHER, H. (1971) Heterozygotie und Fruchtbarkeit bei Rindern. Disch. Tierärztl. Wschr. 78, 111-114.

REMMEN, J.W.A. (1976) Een onderzoek naar mogelijkheden om perinatale sterfte bij het rund te beperken. Thesis, Utrecht.

ROBERTS, S.J. (1971) Veterinary Obstetrics and Genital Diseases. Edwards Brothers, Inc., Ann Arbor, Michigan.

RoINE, K. (1973) The most frequent reproductive disorders and their seasonal variation in dairy cows. Nord. Vet. Med. 25, 242.

Rottensten, K. \& TouchberRy, R.W. (1957) Observations on the degree of expression of estrus in cattle. J. Dairy Sci. 40, 1457-1465.

Schoop, G., KRÜGER-HANSEN, U. \& WAChENDORFER, G. (1965) Zur Isolierung von Miyagawanellen aus abortierten Rinderfeten. Zentbl. VetMed. B 12, 2330.

Shannon, F.D., Salisbury, G.W. \& VanDemark, N.L. (1952) The fertility of cows inseminated at various intervals after calving. J. Anim. Sci. 11, 355360.

SONNENBRODT \& RANNIGER (1950) Die Nymphomanie in der Rindviezucht des Waldviertels (Niederdonau) eine Erbkrankheit. Z. Tierzücht. Zücht. Biol. 58, 108118.

SORENSEN, A.M. (1975) Estrous detection in cattle. Southwestern Vet. 28, 127-143.
SPAlding, R.W., Everett, R.W. \& Foote, R.H. (1975) Fertility in New York artificially inseminated Holstein herds in dairy herd improvement. J. Dairy Sci. 58, 718-723.

STÄMPFLI, G. (1973) Erfahrungen eines Tierartzes bei Untersuchungen über die Herdensterilität. Schweiz. landw. M. 51, 465-482.

Storz, J. (1971) Chlamydia and Chlamydia-Induced Diseases, pp. 175-183. C.C. Thomas, Springfield, Illinois.

StotT, G.H. \& Williams, R.J. (1962) Causes of low breeding efficiency in dairy cattle associated with seasonal high temperatures. J. Dairy Sci. 45, 13691375.

Stott, G.H., Wiersma, F. \& Woods, J.M. (1972) Reproductive health program for cattle subjected to high environmental temperatures. J. Am vet. med. Ass. 161, 1339-1344.

ThatCHeR, W.W. (1974) Effects of season, climate and temperature on reproduction and lactation. J. Dairy Sci. 57, 360-368.

Touchberry, R.W., Rottensten, K. \& ANdersen, H. (1959) Association between service interval from first service to conception and level of butterfat production. J. Dairy Sci. 42, 1157-1170.

Trimberger, G.W. (1954) Conception rates in dairy cattle from services at various intervals after parturition. J. Dairy Sci. 37, 1042-1049.

Trimberger, G.W. \& Davis, G.K. (1943) The relationship between time of insemination and breeding efficiency in dairy cattle. Res. Bull. Neb. agric. Exp. Stn No. 129.

VanDemark, N.L. \& Salisbury, G.W. (1950) The rela. tion of the post partum breeding interval to reproductive efficiency in the dairy cow. J. Dairy Sci. 9, 307-313.

VAN DIETEN, S.W.J. (1963) Mortaliteit van kalveren bij de partus a terme van M.R.Y.-runderen. Thesis, Utrecht.

VAN Dieten, S.W.J. (1964) Fertility after stillbirth in cattle. Proc. 5th Int. Congr. Anim. Reprod. \& A.I., Trento, Vol. V, 177.

VAN DiETEN, S.W.J. (1968) De invloed van enige bedrijfsomstandigheden op de vruchtbaarheid van rundvee Tijdschr. Diergeneesk. 93, 1279-1288.

VINCENT, C.K. (1972) Effects of season and high environmental temperature on fertility in cattle. A review. J. Am. vet. med. Ass. 161, 1333-1338.

Wegner, W. (1973) Genetische Einflüsse auf die Fruchtbarkeit beim Rind. Dtsch. Tierärztl. Wschr. 80, 434-437.

Willems, C.M.T. (1971) Een vergelijking van de bevruchtingsresultaten met K.I. op ligboxstallen en andere stallen I \& II. Tijdschr. Diergeneesk. 96, 215 \& 1457.

Williams, B.M., Shreeve, B.J., Heebert, C.N. \& SwIze, P.W. (1977) Bovine mycotic abortion: some epidemiological aspects. Vet. Rec. 100, 382-385.

Williams, G. (1960) Observations on the fertility of newly established herds. Vet. Rec. 72, 197-200.

Williamson, N.B., Morris, R.S., Blood, D.C. \& CANNON, C.M. (1972) A study of oestrous behaviour and oestrus detection methods in a large commercial dairy herd. Vet. Rec. 91, 50-57. 
WnNTER, A.J. (1973) Vibriosis: toward an understanding of immunity in genital infections. Cornell Vet. 63, 516.

Whitmore, H.L., TYLeR, W.J. \& CAsidA, L.R. (1974a) Effects of early post partum breeding in dairy cattle. J. Anim. Sci. 38, 339-346.

WhITMORE, H.L., TYLER, W.J. \& CASIDA, L.E. (1974b) Incidence of cystic ovaries in Holstein-Friesian cows J. Am. vet. med. Ass. 165, 693-694.

Wolfr, L.K. \& MONTY, D.E. (1974) Physiologic ro- sponse to intense summer heat and its effect on the estrous cycle of nonlactating and lactating HolsteinFriesian cows in Arizona. Am. J. vet. Res. 35, 187192.

ZEMJANIS, R. (1974) Vaccination for reproductive efficiency in cattle. J. Am. vet. med. Ass. 165, 689692.

ZemJanis, R., Fahning, M.L. \& Schulz, R.H. (1969) Anestrus, the practitioners dilemma. Vet. Scope 14, 15-19. 